University of Nebraska - Lincoln

DigitalCommons@University of Nebraska - Lincoln

USDA National Wildlife Research Center - Staff Publications
U.S. Department of Agriculture: Animal and Plant Health Inspection Service

2011

\title{
Mesopredators dominate competition for carrion in an agricultural landscape
}

Travis L. DeVault

USDA/APHIS/WS National Wildlife Research Center, Travis.L.DeVault@aphis.usda.gov

Zachary $\mathrm{H}$. Olson

Purdue University

J. C. Beasley

Purdue University, beasley@srel.uga.edu

Olin E. Rhodes Jr.

Purdue University, rhodes@srel.uga.edu

Follow this and additional works at: https://digitalcommons.unl.edu/icwdm_usdanwrc

Part of the Life Sciences Commons

DeVault, Travis L.; Olson, Zachary H.; Beasley, J. C.; and Rhodes, Olin E. Jr., "Mesopredators dominate competition for carrion in an agricultural landscape" (2011). USDA National Wildlife Research Center Staff Publications. 1303.

https://digitalcommons.unl.edu/icwdm_usdanwrc/1303

This Article is brought to you for free and open access by the U.S. Department of Agriculture: Animal and Plant Health Inspection Service at DigitalCommons@University of Nebraska - Lincoln. It has been accepted for inclusion in USDA National Wildlife Research Center - Staff Publications by an authorized administrator of DigitalCommons@University of Nebraska - Lincoln. 


\title{
Mesopredators dominate competition for carrion in an agricultural landscape
}

\author{
Travis L. DeVault ${ }^{\mathrm{a}, *}$, Zachary H. Olson ${ }^{\mathrm{b}}$, James C. Beasley ${ }^{\mathrm{b}}$, Olin E. Rhodes Jr. ${ }^{\mathrm{b}, \mathrm{c}}$ \\ ${ }^{a}$ United States Department of Agriculture, Wildlife Services, National Wildlife Research Center, 6100 Columbus Avenue, Sandusky, \\ OH 44870, USA \\ ${ }^{\mathrm{b}}$ Department of Forestry and Natural Resources, 195 Marstellar Street, Purdue University, West Lafayette, IN 47907, USA \\ ${ }^{\mathrm{c}}$ United States Department of Agriculture, Wildlife Services, National Wildlife Research Center, 4101 LaPorte Avenue, Fort Collins, \\ CO 80521, USA
}

Received 28 April 2010; accepted 16 February 2011

\begin{abstract}
The role of carrion in food webs is governed by complex competitive interactions among a wide range of taxa. Although this competition is known to be influenced by several biotic and abiotic factors, relatively few data are available from highly altered landscapes. We investigated the fate of mouse carcasses in an intensively farmed region in Indiana, USA, using remote cameras. Vertebrates removed 234 of $266(88 \%)$ carcasses within two weeks after placement. Raccoons (Procyon lotor) and Virginia opossums (Didelphis virginiana) were the predominant scavengers, removing 184 of 197 (93\%) carcasses for which a scavenger could be identified. Air temperature influenced carcass removal by vertebrates only at higher temperatures, with fewer carcasses removed as temperatures increased over $\sim 22^{\circ} \mathrm{C}$. Elevated densities of mesopredators, coupled with the reduced search area for carrion due to the sparse distribution of forested habitat, likely were responsible for the rapid discovery and high level of carcass removal by vertebrates compared to previous investigations. Our data suggest that in agricultural landscapes, the competitive balance for carrion can differ substantially from that found in more pristine habitats. Moreover, the monopolization of carrion resources by abundant mesopredators may have negative consequences for other species that use carrion.
\end{abstract}

\section{Zusammenfassung}

Die Rolle von Aas in Nahrungsnetzen wird von komplexen Konkurrenzbeziehungen zwischen einer Vielzahl von Taxa bestimmt. Obwohl bekannt ist, dass diese Konkurrenz von verschiedenen biotischen und abiotischen Faktoren beeinflusst wird, gibt es relativ wenige Daten aus stark veränderten Landschaften. Wir untersuchten das Schicksal von Mäusekadavern in einer intensiv bewirtschafteten Agrarregion in Indiana, USA, und benutzten dafür fernausgelöste Kameras. Wirbeltiere entfernten 234 von 266 (88\%) Kadavern innerhalb von zwei Wochen nach dem Auslegen. Waschbären (Procyon lotor) und Virginia-Opossums (Didelphis virginiana) waren die dominanten Aasfresser, und sie entfernten 184 von 197 (93\%) Kadavern, bei denen der Aasfresser identifiziert werden konnte. Die Lufttemperatur hatte einen Einfluss: Ab etwa $22^{\circ} \mathrm{C}$ wurden weniger Kadaver weggeräumt. Erhöhte Dichten von Mesoprädatoren, verbunden mit einem durch die spärliche Verteilung der Gehölzhabitate eingeschränkten Suchareal, waren wahrscheinlich dafür verantwortlich, dass die Kadaver verglichen mit früheren Untersuchungen schnell

${ }^{*}$ Corresponding author. Tel.: +1 4196250242; fax: +14196258465 .

E-mail address: Travis.L.DeVault@ aphis.usda.gov (T.L. DeVault). 
entdeckt und zu einem hohen Prozentsatz von Wirbeltieren entfernt wurden. Unsere Daten legen nahe, dass in Agrarlandschaften das Konkurrenzgleichgewicht der Aasnutzer erheblich von dem in eher ursprünglichen Habitaten abweicht. Darüberhinaus könnte die Monopolisierung des Aases durch häufige Mesoprädatoren negative Konsequenzen für andere Arten, die Aas nutzen, haben.

Gesellschaft für Ökologie. Published by Elsevier GmbH.

Keywords: Agriculture; Didelphis virginiana; Diet; Food webs; Fragmentation; Procyon lotor; Scavenging

\section{Introduction}

Ecologists often consider the fate of animal carcasses separately from energy flow between vertebrate consumers via predation (DeVault, Rhodes, \& Shivik 2003). In most foodweb models, animal carcasses are relegated to the detrital subweb, represented only by insects, fungi, and microbial decomposers (e.g., Brewer 1994). However, in a review of 22 studies that experimentally examined the fate of animal carcasses, DeVault et al. (2003) found that, on average, 75\% of animal carcasses were consumed by other vertebrates. These vertebrate scavengers included not only those species typically thought of as prolific carrion-feeders (e.g., turkey vultures, Cathartes aura), but also species generally considered to be predominantly predaceous, such as great-horned owls (Bubo virginianus) and red foxes (Vulpes vulpes). There is a growing recognition that carrion use by these "facultative scavengers" can have far-reaching consequences on ecological communities.

For example, the location and volume of carrion can influence the distribution and abundance of predators and their prey. Several species of avian predators choose foraging or breeding habitats based, at least in part, on carrion availability (Watson, Rae, \& Stillman 1992; Marr, Edge, Anthony, \& Valburg 1995). Cortés-Avizanda, Selva, Carrete, and Donázar (2009) found that the abundance of common ravens (Corvus corax), red foxes, and jays (Garrulus glandarius) increased in the vicinity of ungulate carcasses, whereas the abundance of common prey species decreased, likely as a result of elevated predation by the facultative scavengers, or avoidance of them. Furthermore, Cortés-Avizanda, Carrete, Serrano, and Donázar (2009) demonstrated that predation on artificial nests of ground-nesting birds was elevated near carcasses, presumably because an increased abundance of facultative scavengers were attracted to the carcasses. These studies demonstrate that the presence of carrion affects not only scavengers that directly compete for the resource, but also can influence populations at other trophic levels (see also Janzen 1976; Rose \& Polis 1998; Wilmers, Stahler, Crabtree, Smith, \& Getz 2003; Wilmers, Crabtree, Smith, Murphy, \& Getz 2003; Adams et al. 2010).

Even though vertebrates usually consume the majority of carrion present in ecosystems (DeVault et al. 2003), insects and microbes have evolved effective means of monopolizing carrion (Janzen 1977; Burkepile et al. 2006) and sometimes outcompete vertebrates for available carcasses (DeVault, Brisbin, \& Rhodes 2004). Consequently, in most terrestrial ecosystems the role of carrion in food webs is governed by competition between vertebrate scavengers and decomposers, and among individuals within those groups. Although such competitive interactions are complex, they are not random (Selva \& Fortuna 2007). These recent studies also suggest that there likely are emergent properties of carriondriven food webs, primarily associated with the efficiency of energy transfer back into vertebrate communities. Thus, variance in the efficiency with which energy is transferred back into vertebrate communities, ranging from direct transfer via scavenging to indirect transfer via the invertebrate community, likely is influenced by the interplay of several critical biotic (e.g., availability of live prey) and abiotic (e.g., air temperature) factors (Ferrari \& Weber 1995; DeVault et al. 2004; Selva, Jedrzejewska, Jedrzejewski, \& Wajrak 2005; Parmenter \& MacMahon 2009).

Although our understanding of scavenging ecology has grown over the past decade, most research in this area has been conducted in predominately undisturbed habitats containing relatively intact, diverse vertebrate scavenging communities and large expanses of natural habitat, including Yellowstone National Park in the USA (Wilmers, Stahler, et al. 2003; Wilmers, Crabtree, et al. 2003) and Białowieża Primeval Forest in Poland (Selva et al. 2005; Selva \& Fortuna 2007). Alternatively, relatively few studies have investigated the fate of carrion in highly disturbed, human-dominated habitats, including intensively farmed lands, a major land-use type worldwide where vertebrate communities lack diversity (Benton, Vickery, \& Wilson 2003) and are dominated by a few generalist species (Swihart, Gehring, Kolozsvary, \& Nupp 2003; Prange \& Gehrt 2004).

As such, our goal in this research was to investigate scavenging ecology in a highly disturbed agricultural ecosystem. To achieve this goal we conducted experimental trials to explore competition for small carrion items between scavengers and decomposers in the agricultural ecosystem of northern Indiana, USA, a highly disturbed portion of the Eastern Deciduous Biome that exhibits most of the ecological attributes (e.g., low species diversity, extreme habitat fragmentation, high densities of generalist mesopredators) considered to be typical of agricultural landscapes found throughout temperate regions of the world. Our specific objectives in this research were to (1) evaluate the use of small carcasses by the scavenging community associated with a typical agricultural ecosystem, both in terms of identifying the dominant scavengers and the influence of air temperature on the fate of carcasses, and (2) contrast metrics of scavenging 
ecology associated with a disturbed agricultural ecosystem with those of a relatively undisturbed habitat occurring within the same biome (DeVault \& Rhodes 2002; DeVault et al. 2004) to assess whether described patterns of carcass use that have been documented previously remain despite widespread human disturbances.

The removal of carcasses by vertebrates is considered an ecosystem service (Sekercioglu 2006), and intact, diverse habitats generally provide ecosystem services more efficiently than disturbed or highly altered habitats (Perfecto et al. 2004; Sekercioglu 2010). As such, our a priori expectation was that the efficiency of the scavenging community within the agricultural ecosystem would be directly affected by the low species diversity of that environment, resulting in a lower level of carcass use by vertebrates compared to that found in more natural habitats. We also anticipated that temperature-mediated patterns of scavenging that have been observed previously for carcasses (i.e., increased carcass decomposition at higher temperatures; DeVault et al. 2004) would be more pronounced in the agricultural ecosystem than in the relatively undisturbed environment, primarily due to the lack of diversity in facultative scavengers in the former environment and the anticipated increase in decomposition by insects and microbes.

\section{Materials and methods}

The Upper Wabash River Basin (UWB) is located in northern Indiana, USA, and encompasses $1165 \mathrm{~km}^{2}$. Approximately $71 \%$ of the UWB is cultivated in agricultural production yearly with corn (Zea mays) and soybeans (Glycine max) comprising the primary crops (Beasley, DeVault, \& Rhodes 2007). Only $13 \%$ of the UWB is forested, compared to $19 \%$ statewide (Moore \& Swihart 2005). Remaining forest patches are highly fragmented: $75 \%$ of forest patches were $<5 \mathrm{ha}, 50 \%$ were $<2 \mathrm{ha}$, and $1 \%$ of patches were $>100$ ha (Moore \& Swihart 2005). Raccoons (Procyon lotor) and Virginia opossums (Didelphis virginiana) are the most abundant mesopredators in the landscape; their presence is ubiquitous across the study area (Beasley \& Rhodes 2008; Smyser, Beasley, Olson, \& Rhodes 2010).

We utilized 13 forest patches for our experiments, selected to represent the variance in patch size and patch isolation present in the UWB (Moore \& Swihart 2005; Beasley \& Rhodes 2008). We placed one mouse (Mus musculus) carcass in each of the 13 woodlots bi-weekly from 16 June 2007 through 24 May 2008 such that there were 25 twoweek rounds in each of the 13 woodlots over a calendar year (one round in December 2007 was omitted due to heavy snow). Dark brown mouse carcasses were obtained frozen from a pet-food supplier (MiceDirect, Cleveland, GA, USA) and were of similar mass (mean $=18.4 \mathrm{~g} ; \mathrm{SE}=0.03 \mathrm{~g}$ ) to the white-footed mouse (Peromyscus leucopus), the native mouse common in our study area (mean mass $=17.9 \mathrm{~g} ; \mathrm{SE}=0.16 \mathrm{~g}$; Eagan 2009). The average density of white-footed mice in
UWB woodlots is 23 mice/ha (Eagan 2009), and they likely serve as a common source of carrion there (DeVault et al. 2003). Carcasses were placed randomly within woodlots each round to reduce the potential for site habituation by individual scavengers (DeVault et al. 2004).

The fates of mouse carcasses were monitored using Stealth Cam remote cameras (model STC-WD1; Stealth Cam LLC, Grand Prairie, TX, USA). The cameras were modified to capture images upon activation of a pressure-sensitive trigger mechanism upon which a mouse carcass was placed. A detailed description of the trigger mechanism can be found in DeVault et al. (2004). We attached cameras to tree trunks so that they faced downward at $45^{\circ}$ and were suspended $1.3 \mathrm{~m}$ above the ground. Mouse carcasses were thawed to $\sim 21^{\circ} \mathrm{C}$ and placed approximately $2 \mathrm{~m}$ from the camera on trigger mechanisms embedded flush with the ground. Cameras were programmed to capture a series of three images per trigger activation.

We used camera images to categorize the fates of mouse carcasses as (1) scavenged - the first scavenger to remove the carcass from the trigger was recorded; (2) unknown scavenger - the carcass was removed before advanced decomposition, but a scavenger could not be identified from the images; (3) not scavenged - the carcass was still present on the trigger mechanism at the end of 2-weeks or was severely decomposed; or (4) non-trial - carcass fate could not be assigned (e.g., mechanical malfunction or human error). We documented elapsed time from carcass placement to removal using photographic time-stamps. Following DeVault et al. (2004), we use the term "scavenger" for vertebrates, because they can consume small carrion items individually. We use the term "decomposer" for insects and microbes, which generally can consume only small portions of carcasses individually.

Previous research indicates that ambient air temperature can influence competition for small carrion items between vertebrate scavengers and decomposers (Putman 1983; DeVault \& Rhodes 2002; DeVault et al. 2004). We used a second-order polynomial regression (Statistix 2008) to model the effect of ambient air temperature on the number of carcasses removed by vertebrates per round. Further, following temperature groupings in DeVault et al. (2004), we divided the 25 rounds into "cool-weather" $(n=20$; mean air temperature during the first week of the round ranged from 0.1 to $\left.21.4^{\circ} \mathrm{C}\right)$ and "warm-weather" rounds $(n=5$; $22.4-27.0^{\circ} \mathrm{C}$ ). This grouping allowed us to visualize the effect of ambient air temperature on the temporal patterns of carcass removal by vertebrates, and to compare our results to those of DeVault et al. (2004).

\section{Results}

We censored 59 trials (carcasses) from analyses due to their classification as "non-trial". In the remaining 266 trials, 234 carcasses $(88 \%)$ were removed by vertebrates (Table 1 ). Raccoons and Virginia opossums were the predominant scav- 
Table 1. Numbers of brown-furred house mice (Mus musculus) removed by vertebrate scavengers, as identified by remote cameras in woodlots in Indiana, USA. Three hundred twenty-five mouse carcasses (13 per each of 25 rounds) were monitored over one year; 59 trials (carcasses) were removed from analyses due to camera malfunction.

\begin{tabular}{llc}
\hline Class & Species & Number removed \\
\hline Mammalia & Raccoon & 105 \\
& Virginia opossum & 79 \\
& White-footed mouse & 4 \\
& Long-tailed weasel & 2 \\
& Domestic cat & 2 \\
& Fox squirrel & 1 \\
& White-tailed deer & 1 \\
Aves & Striped skunk & 1 \\
Unknown & Blue jay & 2 \\
Total & & 37 \\
\hline
\end{tabular}

Scientific names are as follows: raccoon, Procyon lotor; Virginia opossum, Didelphis virginiana; white-footed mouse, Peromyscus leucopus; long-tailed weasel, Mustela frenata; Domestic cat, Felis catus; fox squirrel, Sciurus niger; white-tailed deer, Odocoileus virginianus; striped skunk, Mephitis mephitis; blue jay, Cyanocitta cristata.

engers, removing 184 of 197 (93\%) carcasses for which a scavenger could be identified (37 carcasses were assigned a fate of "unknown scavenger"; Table 1). The 50 scavenged carcasses not removed by raccoons or Virginia opossums were attributed to at least 7 other vertebrate species (Table 1). We were able to determine the time of day of carcass removal for all 197 of the carcasses classified as "scavenged"; of these, $183(93 \%)$ were removed at night (between 1800 and $0600 \mathrm{~h}$ ).

Ambient air temperature influenced the probability of carcass removal by vertebrates only at higher temperatures, with fewer carcasses removed by vertebrates as temperatures increased over $\sim 22{ }^{\circ} \mathrm{C}$ (Fig. 1). Vertebrates removed 31 of 49 carcasses $(63 \%)$ during the five warm-weather rounds, and 203 of 217 (94\%) during the 20 cool-weather rounds. Across all temperatures, the mean time to removal was $2.25(\mathrm{SE}=0.17)$ days. Temporal trends for carcass removal between warm- and cool-weather rounds were similar until approximately 2.5 days after carcass placement (Fig. 2). During warm-weather rounds, only one carcass was scavenged after 4 days. Conversely, during cool-weather rounds, carcasses were removed by vertebrates up to 11.5 days past carcass placement (Fig. 2).

\section{Discussion}

Despite our prediction that the lack of species diversity in facultative scavengers would result in decreased scavenging efficiency, the overwhelming majority of mouse carcasses $(88 \%)$ experimentally placed in our study area was removed by vertebrates. This high level of scavenging efficiency con-

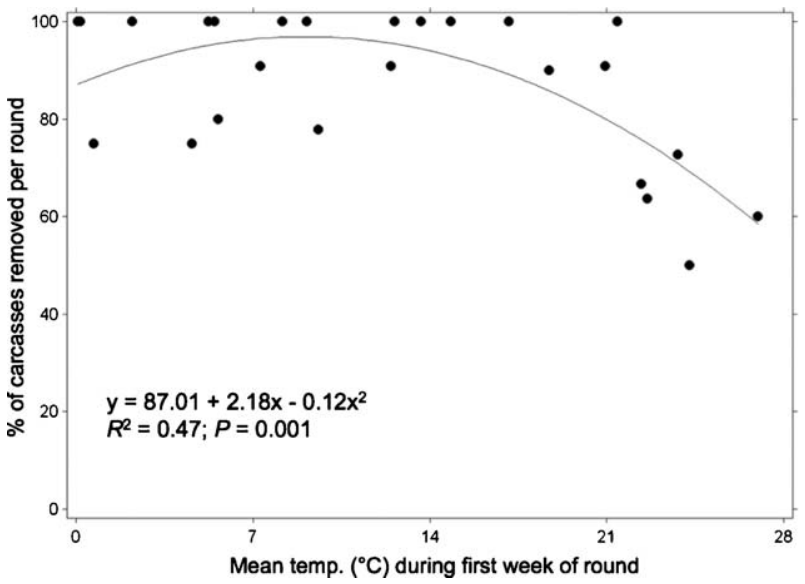

Fig. 1. Percentage of carcasses removed by vertebrates per round in relation to the mean ambient air temperature during the first week of the round. There were 25 two-week rounds, during which 13 carcasses were placed randomly in woodlots (one carcass per woodlot).

trasts with previous work in large, contiguous forests in South Carolina, USA (30\% for mice across one year, DeVault et al. 2004; 67\% for mice during winter, DeVault \& Rhodes 2002), but falls within the range of values reported for vertebrates (DeVault et al. 2003). It is likely that elevated densities of raccoons and Virginia opossums in our study area (Beasley \& Rhodes 2008; Smyser et al. 2010) contributed extensively to the high levels of scavenging efficiency we observed, as abundances of these species in the UWB greatly exceed those of populations occurring in less disturbed landscapes. For

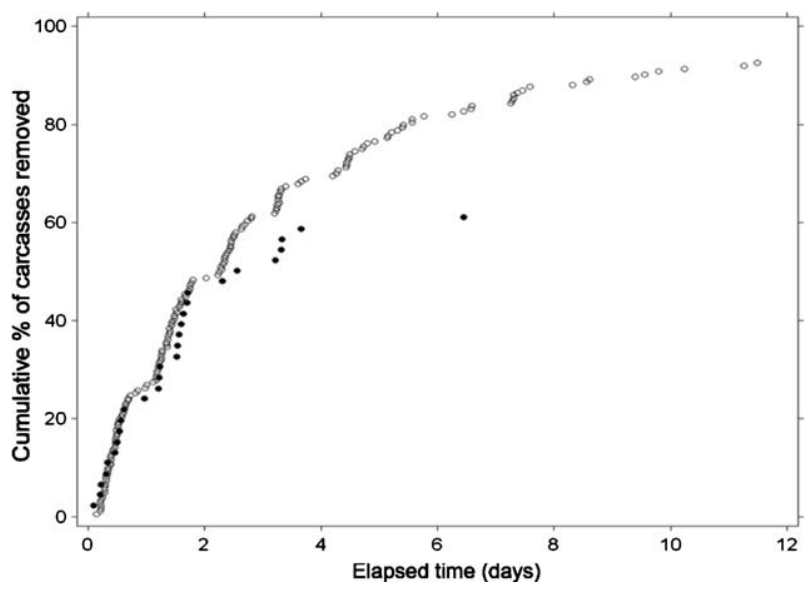

Fig. 2. Temporal trend in carcass removal by vertebrates during warm weather rounds $(n=5)$ and cool weather rounds $(n=20)$. Each circle represents a scavenging event. Warm-weather rounds (solid circles) are those for which the mean air temperature during the first week of the two-week round was $22.4-27.0^{\circ} \mathrm{C}$; during cool-weather rounds (open circles), the mean air temperature during the first week of the round was $0.1-21.4{ }^{\circ} \mathrm{C}$ (DeVault et al. 2004). Thirty-seven scavenged carcasses were omitted from this analysis because a time stamp was not available on the camera images. 
example, patch-specific raccoon densities in the UWB can reach 38 adult raccoons $/ \mathrm{km}^{2}$ during spring (JCB, unpublished manuscript). The high level of habitat fragmentation within our study landscape undoubtedly contributed to the efficiency of vertebrate scavengers in our study. Within the UWB, only $13 \%$ of the landscape was forested, concentrating the movements of most terrestrial vertebrates within a small fraction of the overall land area (Beasley, DeVault, \& Rhodes 2007; Beasley \& Rhodes 2010).

Although air temperature has been identified as a key predictor of scavenging efficiency in earlier studies (DeVault \& Rhodes 2002; DeVault et al. 2004; Selva et al. 2005), it appeared to be less important in this fragmented agricultural ecosystem, probably because a substantial number of carcasses were consumed by raccoons and Virginia opossums before they decomposed. However, the reduced number of carcasses removed by vertebrates during summer suggests that air temperature influenced the fate of carcasses at least marginally. It should be noted, however, that during summer in the UWB, natural food items eaten by raccoon increase in abundance and this species forages for corn in agricultural fields to a greater degree than during other seasons (Beasley, DeVault, Retamosa, \& Rhodes 2007). Consequently, it is not completely clear whether the lower scavenging efficiency observed during summer was due to higher temperatures and increased competition with decomposers for carcasses, or the availability of plentiful alternative resources during that season. We also acknowledge the possibility that reduced activity by endothermic scavengers during high temperatures (Speakman \& Król 2010) could have contributed to lower scavenging efficiency during warm weather.

The temporal pattern of carcass removal by vertebrates differed considerably from that observed by DeVault et al. (2004) in the more continuously forested landscape of South Carolina. At two days past carcass placement approximately $60 \%$ and $76 \%$ fewer carcasses had been removed by vertebrates during cool-weather and warm-weather rounds in South Carolina, respectively (Fig. 2; weather groupings were similar between the two studies), indicating that in the highly fragmented agricultural ecosystem we studied in northern Indiana, vertebrates discovered and removed carcasses more rapidly than was observed in the earlier study (DeVault et al. 2004). Moreover, in South Carolina no mouse carcasses were removed by vertebrates after two days past carcass placement during warm weather (suggesting that all carcasses were completely decomposed or made unsuitable by microbes for vertebrate consumption by that time), whereas in northern Indiana mouse carcasses were removed consistently until four days past carcass placement during warm weather (Fig. 2). Even though we did not directly study decomposition processes, this longer period of carrion foraging by vertebrates in the current study suggests that carcasses probably decomposed more slowly in northern Indiana than in South Carolina during warm weather (DeVault et al. 2004). Both of these factors - more rapid discovery and removal of carcasses and slower decomposition - likely led to the greater level of scavenging efficiency observed in the current study. Elevated densities of raccoons and Virginia opossums, coupled with the reduced search areas in which these species had to find carcasses, likely were responsible for the more rapid discovery and removal of carcasses in the agricultural ecosystem we investigated. Although the factors responsible for slower decomposition evident in the current study are unknown, it is possible that differences in insect communities played a role. For example, imported fire ants (Solenopsis invicta) are absent in Indiana and common in South Carolina (Callcott \& Collins 1996). Because insects are generally able to consume small carcasses before microbes are able to monopolize them (DeVault et al. 2004), we suspect that insects were more important to the decomposition process than microbes in our study.

The relatively low diversity of scavengers we recorded was expected given the species-poor nature of most vertebrate communities found in intensively farmed landscapes (Benton et al. 2003; Swihart et al. 2003). Mesopredators, however, often thrive in fragmented, human-altered landscapes (Oehler \& Litvaitis 1996), due to the loss of top predators (reviewed in Ritchie \& Johnson 2009) or increases in food availability (Litvaitis \& Villafuerte 1996; Prange \& Gehrt 2004). Even so, despite the abundance of mesopredators in our study area, the near lack of birds (one species removed two carcasses) and complete lack of snakes observed scavenging was somewhat surprising. It is clear that in human-altered, agricultural landscapes, where species diversity is often limited and mesopredators are abundant, the competitive balance for small carrion items can differ substantially from that found in more pristine habitats.

The various ecological implications of elevated mesopredator abundance have been discussed extensively (e.g., Crooks \& Soulé 1999; Prugh et al. 2009; Ritchie \& Johnson 2009). However, the monopolization of carrion resources by raccoons and other mesopredators in agricultural landscapes has escaped notice, and likely represents another example of indirect negative impacts of human land-use on ecological processes. Our results, combined with our previous studies (DeVault \& Rhodes 2002; DeVault et al. 2004), demonstrate that mesopredators, and raccoons in particular, are extremely effective scavengers of small carrion items. Furthermore, our prediction that the efficiency of the vertebrate scavenging community within our highly altered agricultural study area would be lower than that found in the more pristine and diverse environment in South Carolina studied by DeVault et al. (2004) was negated primarily by the unmatched ability of raccoons and Virginia opossums to find and consume small carcasses. Thus, our results may reflect aspects of the "sampling effect" (Huston 1997; Wardle 1999), which asserts that it is not elevated diversity per se that increases the efficiency of some ecosystem services, but rather the greater probability that more diverse ecosystems will contain at least one highly efficient species. In our case, even though our highly altered agricultural study area had relatively low vertebrate diversity, 
it harboured two extremely effective vertebrate scavenger species in high numbers.

The abundance of raccoons and other common mesopredators over much of their range (Prugh et al. 2009) may have negative consequences for other species that use carrion resources. For example, an inverse relationship has been demonstrated between the abundance and diversity of burying beetles (Nicrophorus spp.) and the level of forest fragmentation (Gibbs \& Stanton 2001). Nicrophorus beetles are obligate carrion breeders that rely completely on small carcasses (4-100 g) for reproduction (Scott 1998). The American burying beetle (N. americanus) was placed on the USA federal endangered species list in 1989, and although the factors responsible for its decline are not completely understood, Sikes and Raithel (2002) cited competition with vertebrates for small carcasses as one of the most likely contributors. It is possible that the extraordinary ecological success of raccoons and other mesopredators in highly altered landscapes - and their ability to monopolize carrion resources - has contributed to the decline of the American burying beetle. The relationship between mesopredator abundance and conservation status of the American burying beetle should be examined more closely. Many other organisms that use carrion, either as a principal food resource or as a buffer when primary prey populations decline (DeVault et al. 2003), also may be adversely affected in this way.

Our study has confirmed that human-induced changes to vertebrate communities can significantly influence the scavenging ecology of organisms within agricultural ecosystems. Given the intensification of agricultural land worldwide, our findings may have important implications for understanding how changes in land-use practices can affect species interactions in disturbed ecosystems.

\section{Acknowledgments}

We thank the landowners in the UWB for providing access to their land, and T. Atwood, B. Blackwell, J. Schmidt, P. Schmidt, T. Seamans, S. Werner, and anonymous reviewers for thoughtful comments on the manuscript. Funding was provided by the Purdue University Department of Forestry and Natural Resources.

\section{References}

Adams, L. G., Farley, S. D., Stricker, C. A., Demma, D. J., Roffler, G. H., Miller, D. C., et al. (2010). Are inland wolf-ungulate systems influenced by marine subsidies of Pacific salmon? Ecological Applications, 20, 251-262.

Beasley, J. C., DeVault, T. L., \& Rhodes, O. E., Jr. (2007). Home range attributes of raccoons in a fragmented agricultural region of northern Indiana. Journal of Wildlife Management, 71, 844-850.

Beasley, J. C., DeVault, T. L., Retamosa, M. I., \& Rhodes, O. E., Jr. (2007). A hierarchical analysis of habitat selection by rac- coons in northern Indiana. Journal of Wildlife Management, 71, 1125-1133.

Beasley, J. C., \& Rhodes, O. E., Jr. (2008). Relationship between raccoon abundance and crop damage. Human-Wildlife Conflicts, 2, 36-47.

Beasley, J. C., \& Rhodes, O. E., Jr. (2010). Influence of patch- and landscape-level attributes on the movement behavior of raccoons in agriculturally fragmented landscapes. Canadian Journal of Zoology, 88, 161-169.

Benton, T. G., Vickery, J. A., \& Wilson, J. D. (2003). Farmland biodiversity: Is habitat heterogeneity the key? Trends in Ecology and Evolution, 18, 182-188.

Brewer, R. (1994). The science of ecology (second ed.). Orlando, Florida: Saunders College Publishing.

Burkepile, D. E., Parker, J. D., Woodson, C. B., Mills, H. J., Kubanek, J., Sobecky, P. A., et al. (2006). Chemically mediated competition between microbes and animals: Microbes as consumers in food webs. Ecology, 87, 2821-2831.

Callcott, A. A., \& Collins, H. L. (1996). Invasion and range expansion of imported fire ants (Hymenoptera: Formicidae) in North America from 1918 to 1995. The Florida Entomologist, 79, 240-251.

Cortés-Avizanda, A., Selva, N., Carrete, M., \& Donázar, J. A. (2009). Effects of carrion resources on herbivore spatial distribution are mediated by facultative scavengers. Basic and Applied Ecology, 10, 265-272.

Cortés-Avizanda, A., Carrete, M., Serrano, D., \& Donázar, J. A. (2009). Carcasses increase the probability of predation of ground-nesting birds: A caveat regarding the conservation value of vulture restaurants. Animal Conservation, 12, 85-88.

Crooks, K. R., \& Soulé, M. E. (1999). Mesopredator release and avifaunal extinctions in a fragmented system. Nature, 400, 563-566.

DeVault, T. L., Brisbin, I. L., Jr., \& Rhodes, O. E., Jr. (2004). Factors influencing the acquisition of rodent carrion by vertebrate scavengers and decomposers. Canadian Journal of Zoology, 82, 502-509.

DeVault, T. L., \& Rhodes, O. E., Jr. (2002). Identification of vertebrate scavengers of small mammal carcasses in a forested landscape. Acta Theriologica, 47, 185-192.

DeVault, T. L., Rhodes, O. E., Jr., \& Shivik, J. A. (2003). Scavenging by vertebrates: Behavioral, ecological, and evolutionary perspectives on an important energy transfer pathway in terrestrial ecosystems. Oikos, 102, 225-234.

Eagan, T.S., II (2009). Disease and predator ecology of white-footed mice in the Upper Wabash River Basin. M.S. thesis. Purdue University, West Lafayette, IN, USA.

Ferrari, N., \& Weber, J. M. (1995). Influence of the abundance of food resources on the feeding habits of the red fox, Vulpes vulpes, in western Switzerland. Journal of Zoology, London, 236, 117-129.

Gibbs, J. P., \& Stanton, E. J. (2001). Habitat fragmentation and arthropod community change: Carrion beetles, phoretic mites, and flies. Ecological Applications, 11, 79-85.

Huston, M. A. (1997). Hidden treatments in ecological experiments: Re-evaluating the ecosystem function of biodiversity. Oecologia, 110, 449-460.

Janzen, D. H. (1976). The depression of reptile biomass by large herbivores. American Naturalist, 110, 371-400.

Janzen, D. H. (1977). Why fruits rot, seeds mold, and meat spoils. American Naturalist, 111, 691-713. 
Litvaitis, J. A., \& Villafuerte, R. (1996). Intraguild predation, mesopredator release, and prey stability. Conservation Biology, 10, 676-677.

Marr, N. V., Edge, W. D., Anthony, R. G., \& Valburg, R. (1995). Sheep carcass availability and use by bald eagles. Wilson Bulletin, 107, 251-257.

Moore, J. E., \& Swihart, R. K. (2005). Modeling site occupancy by forest rodents: Incorporating detectability and spatial autocorrelation with hierarchically structured data. Journal of Wildlife Management, 69, 933-949.

Oehler, J. D., \& Litvaitis, J. A. (1996). The role of spatial scale in understanding responses of medium-sized carnivores to forest fragmentation. Canadian Journal of Zoology, 74, 2070-2079.

Parmenter, R. R., \& MacMahon, J. A. (2009). Carrion decomposition and nutrient cycling in a semiarid shrub-steppe ecosystem. Ecological Monographs, 79, 637-661.

Perfecto, I., Vandermeer, J. H., Bautista, G. L., Nunez, G. I., Greenberg, R., Bichier, P., et al. (2004). Greater predation in shaded coffee farms: The role of resident neotropical birds. Ecology, 85, 2677-2681.

Prange, S., \& Gehrt, S. D. (2004). Changes in mesopredatorcommunity structure in response to urbanization. Canadian Journal of Zoology, 82, 1804-1817.

Prugh, L. R., Stoner, C. J., Epps, C. W., Bean, W. T., Ripple, W. J., Laliberte, A. S., et al. (2009). The rise of the mesopredator. Bioscience, 59, 779-791.

Putman, R. J. (1983). Carrion and dung: The decomposition of animal wastes. London: Edward Arnold.

Ritchie, E. G., \& Johnson, C. N. (2009). Predator interactions, mesopredator release and biodiversity conservation. Ecology Letters, 12, 982-998.

Rose, M. D., \& Polis, G. A. (1998). The distribution and abundance of coyotes: The effects of allochthonous food subsidies from the sea. Ecology, 79, 998-1007.

Scott, M. P. (1998). The ecology and behavior of burying beetles. Annual Review of Entomology, 43, 595-618.

Sekercioglu, C. H. (2006). Increasing awareness of avian ecological function. Trends in Ecology and Evolution, 21, 464-471.

Sekercioglu, C. H. (2010). Ecosystem functions and services. In N. S. Sodhi, \& P. R. Ehrlich (Eds.), Conservation biology for all (pp. 45-72). Oxford: Oxford University Press.
Selva, N., \& Fortuna, M. A. (2007). The nested structure of a scavenger community. Proceedings of the Royal Society B: Biological Sciences, 274, 1101-1108.

Selva, N., Jedrzejewska, B., Jedrzejewski, W., \& Wajrak, A. (2005). Factors affecting carcass use by a guild of scavengers in European temperate woodland. Canadian Journal of Zoology, 83, 1590-1601.

Sikes, D. S., \& Raithel, C. J. (2002). A review of hypotheses of decline of the endangered American burying beetle (Silphidae: Nicrophorus americanus Olivier). Journal of Insect Conservation, 6, 103-113.

Smyser, T. J., Beasley, J. C., Olson, Z. H., \& Rhodes, O. E., Jr (2010). Use of rhodamine B to reveal patterns of interspecific competition and bait acceptance in raccoons. Journal of Wildlife Management, 74, 1405-1416.

Speakman, J. R., \& Król, E. (2010). Maximal heat dissipation capacity and hyperthermia risk: Neglected key factors in the ecology of endotherms. Journal of Animal Ecology, 79, 726-746.

Statistix (2008). Statistix 9 user's manual. Tallahassee, Florida: Analytical Software.

Swihart, R. K., Gehring, T. M., Kolozsvary, M. B., \& Nupp, T. E. (2003). Responses of 'resistant' vertebrates to habitat loss and fragmentation: The importance of niche breadth and range boundaries. Diversity and Distributions, 9, 1-18.

Wardle, D. A. (1999). Is "sampling effect" a problem for experiments investigating biodiversity-ecosystem function relationships? Oikos, 87, 403-407.

Watson, J., Rae, S. R., \& Stillman, R. (1992). Nesting density and breeding success of golden eagles in relation to food supply in Scotland. Journal of Animal Ecology, 61, 543-550.

Wilmers, C. C., Stahler, D. R., Crabtree, R. L., Smith, D. W., \& Getz, W. M. (2003). Resource dispersion and consumer dominance: Scavenging at wolf- and hunter-killed carcasses in Greater Yellowstone, USA. Ecology Letters, 6, 996-1003.

Wilmers, C. C., Crabtree, R. L., Smith, D. W., Murphy, K. M., \& Getz, W. M. (2003). Trophic facilitation by introduced top predators: Grey wolf subsidies to scavengers in Yellowstone National Park. Journal of Animal Ecology, 72, 909-916.

Available online at www.sciencedirect.com

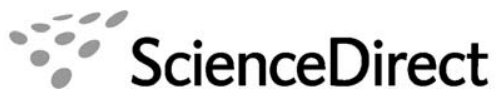

